\title{
Planning and treatment in oral rehabilitation with implant-supported prostheses using cephalometric analysis
}

\author{
Planejamento e tratamento em reabilitação oral com próteses sobre implantes usando análise \\ cefalométrica
}

Adriana Fonseca BORGES

Mariana Ribeiro de Moraes REGO²

Alexandre Milton CORRÊA ${ }^{3}$

Marcelo Ferreira TORRES 4

Daniel de Moraes TELLES 2

Luiz Carlos SANTIAGO5

\begin{abstract}
There are growing prosthetic and esthetic demands for Oral Rehabilitations on osseointegratable implants, requiring precise prosthetic-surgical planning. In edentulous patients planning may be done using cephalometric analysis to determine the position of the teeth in the dental prosthesis, and consequently, those of the implants. In this clinical case, the planning and treatment of an oral implant-supported rehabilitation is described, using cephalometry to optimize prosthetic success and patient comfort. The patient presented complete mandibular and partial maxillary edentulism, with unsatisfactory esthetics and function of the anterior teeth, with accentuated vestibular inclination. In order to determine the correct position of maxillary teeth it was necessary to use a Steiner cephalometric tracing to position the maxillary central incisor in the diagnostic wax-up. Therefore, the maxillary anterior teeth were extracted, osseointegratable implants were placed (Neodent ${ }^{\circledR}$, Curitiba, Brazil), and an immediate temporary fixed denture was inserted. After 30 days, surgery was performed for the placement of 4 osseointegratable implants (Neodent ${ }^{\circledR}$, Curitiba, Brazil) in the inter-mentonian region, on which a complete, temporary, implant-supported denture was placed. After the period of osseointegration, the definitive implant-supported dental prosthesis were fabricated.
\end{abstract}

Indexing terms: Cephalometry. Dental implantation. Dental prosthesis.

\section{RESUMO}

Reabilitações orais sobre implantes osteointegráveis enfrentam crescentes exigências protéticas e estéticas, necessitando de um planejamento protético-cirúrgico preciso. O planejamento em pacientes edêntulos pode ser realizado usando análise cefalométrica para determinar o posicionamento dos dentes na prótese e conseqüentemente dos implantes. Esse caso clínico descreve o planejamento e tratamento de uma reabilitação oral sobre implantes usando análise cefalométrica para otimizar o sucesso protético assim como o conforto do paciente. Paciente apresentando edentulismo total mandibular e parcial maxilar com elementos anteriores insatisfatórios estética e funcionalmente, com inclinação vestibular acentuada. Para a determinação do correto posicionamento dos elementos superiores foi necessário a utilização de traçado cefalométrico de Steiner para o posicionamento do incisivo central superior no enceramento diagnóstico. Dessa forma, foi realizado exodontia dos elementos anteriores superiores, instalação de implantes osteointegraveis (Neodent ${ }^{\circledR}$, Curitiba, Brasil) e instalação de prótese fixa provisória imediata. Após 30 dias, foi realizada cirurgia para instalação de 4 implantes osteointegráveis (Neodent ${ }^{\circledR}$, Curitiba, Brasil) na região intermentoniana, sobre os quais foi instalada uma prótese total implanto-suportada inferior provisória. Após período de osteointegração, as próteses sobre implantes definitivas foram confeccionadas.

Termos de indexação: Circunferência craniana. Implantação dentária. Prótese dentária.

\section{INTRODUCTION}

In edentulous patients, the artificial teeth are positioned in the complete removable denture by adjustments in the wax rim and try-in of the tooth arrangement in order to achieve esthetic and functional harmony ${ }^{1-3}$. However, in cases of patients who have mal-position teeth that need to be extracted, and immediate placement of dental prostheses. it is impossible to use these method because of the presence these teeth in the arch. This makes it imperative to perform a cephalometric evaluation to guide the positioning of the teeth in the denture ${ }^{4}$.

Steiner ${ }^{5-6}$, in his cephalometric studies, determined standard measurements of both the angle formed by the intersection of the long axis of the maxillary central incisor (1/) with line N-A (of the most anterior point of the

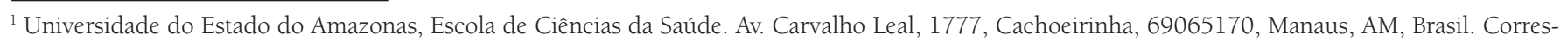
pondência para / Correspondence to: AF BORGES. E-mail: <driborges@gmail.com>.

${ }^{2}$ Universidade do Estado do Rio de Janeiro, Faculdade de Odontologia, Departamento de Prótese. Rio de Janeiro, RJ, Brasil.

${ }^{3}$ Secretaria de Estado de Saúde do Amazonas, Policlínica Governador Gilberto Mestrinho, Manaus, AM, Brasil.

${ }^{4}$ Polícia Militar do Estado do Rio de Janeiro, Odonto Clínica da Polícia Militar do Estado do Rio de Janeiro. Rio de Janeiro, RJ, Brasil.

${ }^{5}$ Universidade Federal do Rio de Janeiro, Faculdade de Odontologia, Departamento de Prótese e Materais Dentários. Rio de Janeiro, RJ, Brasil.
} 
frontonasal suture up to the deepest point of the pre-maxilla contour) and the linear distance of the most prominent point of the maxillary central incisor crown up to line N-A. This analysis expresses the antero-posterior relation of the central incisor in relation to line N-A. Therefore, in a prosthetic planning, the difference between the standard measurements and those of the patient will determine (in degrees and $\mathrm{mm}$ ) where the artificial central incisor should be positioned in relation to the contralateral central incisor. In addition, the distance from the incisal edge to the occlusal plane must be equal to zero, determining the vertical position of the tooth. From then on, the arrangement of the other teeth will be guided by the new position of this maxillary central incisor.

With high success rates both in placement of osseointegratable implants immediately after tooth extraction ${ }^{7-8}$, and in the application of immediate loading ${ }^{9-11}$, the use of new surgical and prosthetic protocols $s^{12-14}$ have allowed the simplification and swift placement of dental prosthesis.

For the fabrication of a complete immediate implant-supported dental prosthesis, some authors 14-17 have described the fabrication of a metal substructure, but this depends on laboratory stages for casting, mounting, polymerization, finishing and polishing of the dentures, increasing the time of work. Bearing this in mind, prefabricated devices have been developed and make it possible to eliminate the laboratory stages, resulting in the fabrication and conclusion of the denture as soon as the implant placement has been concluded.

Mish $^{18}$ described the technique of transforming the complete removable denture into a complete implantsupported denture without the use of a cast bar, but with abutments that have an external surface designed to remain retained on the denture by fixation with acrylic resin.

In the mandible, due to the positioning of implants in the inter-mentonian region, this denture is fabricated with a cantilever extension to guarantee the patient good masticatory capacity in the molar region ${ }^{18}$, but this cantilever is more susceptible to fracture without the presence of a substructure. For this reason, the use of the Distal Bar technique (Neodent, Curitiba, Brazil) is indicated.

\section{CLINICAL CASE}

The patient MAD, a 67-year-old woman, presented complete mandibular edentulism rehabilitated with a complete mandibular removable denture; and partial maxillary edentulism rehabilitated with a partial removable denture with superior posterior clips, and esthetically and functionally unsatisfactory total metal ceramic crowns on the anterior teeth that presented accentuated vestibular inclination.

In the radiographic exam, images suggestive of fracture in the maxillary right central incisor, maxillary right lateral incisor, and in the maxillary left canine were observed, in addition to inadequate periodontal implantation of six elements. During diagnosis and planning, the option was taken to extract the maxillary teeth, later insert osseointegratable implants, and fabricate immediate fixed dentures for the maxillary and mandibular arches.

To determine the correct positioning of the new maxillary teeth, the Steiner cephalometric tracing technique (Figure 1) was used to position the maxillary central incisor during the diagnostic wax-up, since the teeth present were vestibularized and did not serve as a functional and esthetic reference.

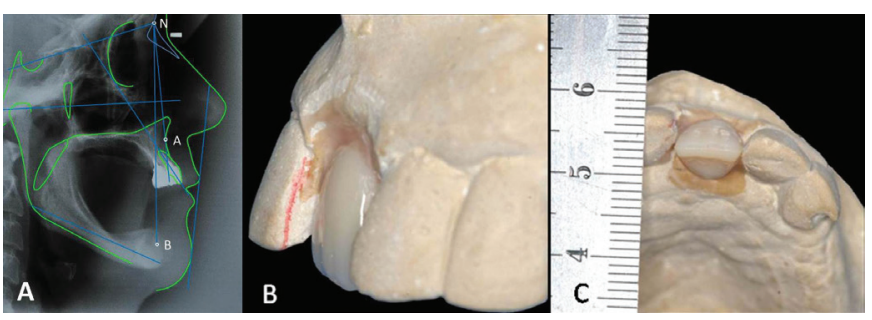

Figure 1. (A) Cephalometry with Steiner tracer. (B) Side view of new position of maxillary central incisor. (C) Occlusal view of new position of maxillary central incisor.

In the Steiner tracing, the standard measurement of the angle formed by the intersection of the long axis of the maxillary central incisor (1/) with the line of the most anterior point of the frontonasal suture up to the deepest point of the premaxilla contour ( $\mathrm{N}-\mathrm{A}$ ) is equal to $22^{\circ}$ and the linear distance from the most prominent point of the maxillary central incisor crown up to the line $\mathrm{N}$-A equal to 4 $\mathrm{mm}^{5-6}$. In this patient, the measurements found were $28.1^{\circ}$ and $8.18 \mathrm{~mm}$ respectively. Therefore, for the diagnostic wax-up, the maxillary central incisor was positioned with an inclination of 6 degrees and 4 millimeters more in the palatine direction in relation to the incisor of the other quadrant (Figure 1).

From the new position of this incisor, the arrangement of the other maxillary and mandibular teeth followed, and a new complete mandibular denture was fabricated, because the new position of the teeth in the 
temporary maxillary denture did not allow an adequate occlusion with the complete mandibular denture in use at the beginning of the case.

Multifunctional guides were fabricated for both the maxilla and mandible from the new arrangement of the teeth, and with the tomographic exam, six osseointegratable implants were planned in the maxilla and four in the mandible (inter-mentionian region). Thus the surgical procedure was performed for extraction of the maxillary anterior teeth and immediate placement of osseointegratable implants (Alvim Ti, Ø4.3; Neodent, Curitiba, Brazil) in the region of the central incisors and canines that presented initial stability greater than $35 \mathrm{~N} / \mathrm{cm}$, which were used as abutments for a temporary complete maxillary fixed denture. Another two osseointegratable implants (Alvim Ti, $\varnothing 4.3$, Neodent, Curitiba, Brazil) were placed in the posterior region of the maxilla, with one being placed in each antimer, which were not used for immediate loading, as they presented initial stability lower than $35 \mathrm{~N} / \mathrm{cm}$.

For fabrication of the immediate maxillary temporary denture on the implants, preparable abutments (Neodent, Curitiba, Paraná, Brazil) were positioned on the implants and prepared. An acetate matrix, fabricated from the diagnostic wax-up (Figure 2) was filled with selfpolymerizing acrylic resin (Dencril, color 62, Caieiras, Brazil) and placed in position for fixation of the abutments. After resin polymerization, the denture was removed and adjustments were made for good adaptation and easy cleaning (Figure 2). The temporary denture was screwretained and access to the screws closed with acrylic resin. Ten days after surgery, the sutures were removed without removing the temporary denture (Figure 2);

After 30 days, surgery was performed in the mandibular arch to insert four osseointegratable implants (Titamax Ti $\varnothing$ 4.0; Neodent, Curitiba, Brazil), in the intermentonian region. The implants were tightened with a torque of over $45 \mathrm{~N} / \mathrm{Cm}$.

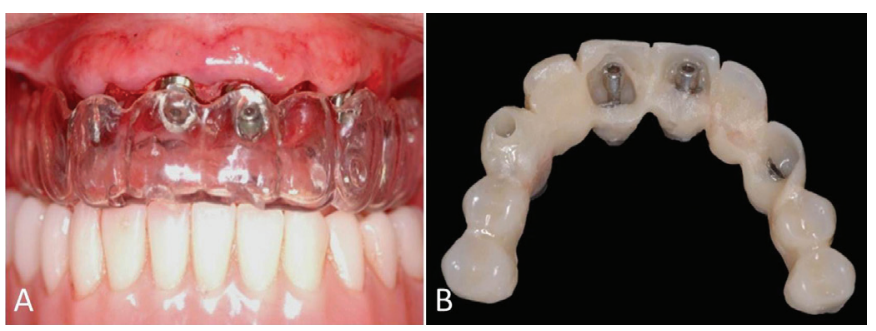

Figure 2. (A) Acetate matrix fabricated from the diagnostic wax-up for fabrication of the temporary denture after placement of the osseointegratable implants. (B) Occlusal view of the maxillary temporary denture with the abutments fixed.
For fabrication of the complete mandibular immediate implant-supported denture, the distal bar technique was used (Neodent, Curitiba, Brazil), which consists of the insertion of prefabricated components, and transformation of the complete removable denture into a complete implant-supported fixed denture. For this purpose, conical mini-abutments with $\varnothing 4.1 \mathrm{~mm}$ and height of $4 \mathrm{~mm}$ (Neodent, Curitiba, Brazil) were fixed on the implants. On the most distal mini-abutments, cylinders with a distal bar, and on the intermediate abutments, straight cylinders were fixed (Figure 3).

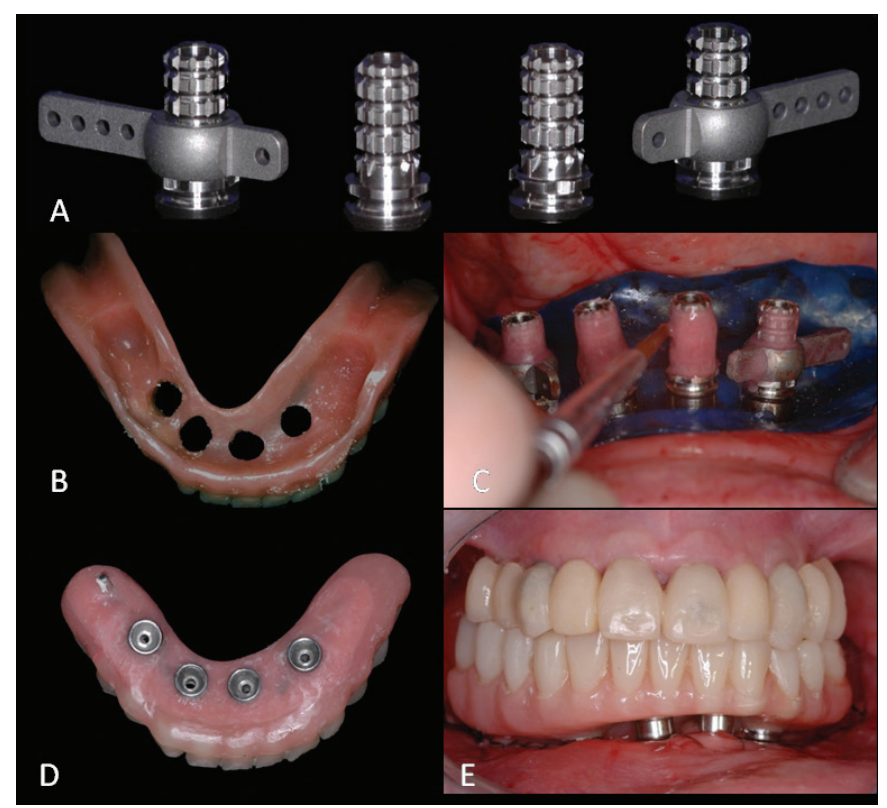

Figure 3. (A) Abutments of the Distal Bar System; (B) Gingival aspect of the complete removable denture after wear with burs to adapt it to the abutments that are positioned in the mouth; (C) Components placed and deposition of acrylic resin with paint brush to guarantee their retention on the abutments; (D) Gingival view of the implant supported denture after due wear performed to diminish the extension in cantilever and guarantee convex gingival surface; ( $E$ ) Front view of the maxillary and mandibular implant supported dentures on the day of the second surgery.

A rubber sheet with perforations over the implants was put into place to isolate the surgical area. The complete mandibular denture used by the patient was internally worn, so that it could be placed in occlusion with the maxillary denture, without interference of the cylinders and distal bar (Figure 3. For this fixation, self-polymerizing acrylic resin (Kooliner; GC America INC., Alsip, Illinois, USA) was used on the retentive areas of the abutments (Figure 3) and filling the internal region of the denture. The denture was put into place, occluding against the maxillary denture, taking care to remove the resin over the access to the screws of the cylinders. After the resin had set, the abutments were unscrewed and the denture with the fixed abutments was removed. 
Cuts were made to reduce the cantilever and make the gingival surface of the denture convex, in order to allow adequate cleaning (Figure 3). The mandibular denture was inserted with a torque of $20 \mathrm{~N} / \mathrm{cm}$ on the mini-abutments, and $10 \mathrm{~N} / \mathrm{cm}$ on the abutment screws.

After the period of osseointegration, the temporary maxillary and mandibular dentures were removed, and the impression-taking procedure was performed for fabrication of the definitive dental prostheses. For this purpose, open tray transfers (Neodent, Curitiba, Brazil) were put into place and joined with dental floss and acrylic resin Pattern; GC America INC., Alsip, Illinois, USA). Using individual open trays of self-polymerizable acrylic resin (Dencril colorless, Caieiras, São Paulo, Brazil) impressions of the arches were taken with polyether (Impregum F; 3M Espe, St. Paul, MN, USA).

The temporary dentures were screw-retained on the casts so that their mounting in the semi-adjustable articular could be performed with the VDO and MHI relations determined by these temporary dentures. The casts and articulator were sent to the laboratory for customization and casting of the UCLA abutments (Neodent, Curitiba, Brazil), fabrication of the metal infrastructure for the cemented metal ceramic denture, and fabrication of the metal structure on the UCLA abutment (Neodent, Curitiba, Brazil) for the mandibular denture.

The customized UCLA abutments were screwretained and the infrastructure segmented, positioned (Figure 4) so that welding could be performed with selfpolymerizing acrylic resin (Pattern; GC America INC., Alsip, Illinois, USA) (Figure 4). The maxillary denture infrastructure was sent to the laboratory to perform the welding and later application of ceramic. On the mandibular denture infrastructure, artificial teeth were arranged for later pressing of the definitive denture.

The mandibular denture and the maxillary cast abutments were screw-retained with a torque of $24 \mathrm{~N} /$ $\mathrm{cm}$, and access to the screw was filled with gutta-percha (Dentsply, Petrópolis, Brazil). The metal ceramic denture was put into place and after the due esthetic and occlusal adjustments, was finished and polished and then cemented with temporary cement (Rely X Temp NE; 3M Espe, St. Paul, MN, USA).

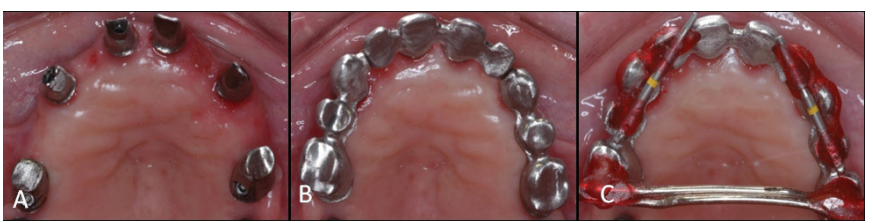

Figure 4. (A) Customized and cast UCLA type abutments in position; (B) Occlusal view of the metal infrastructure of the sectioned metal ceramic denture; (C) Performing intraoral welding.
Panoramic and periapical radiographs have periodically been taken, and maintenance appointments have been made for control of oral hygiene. After the elapse of two years from the time of definitive denture placement, no intercurrence has been observed (Figure 5).

The patient signed a Term of Free and Informed Consent, authorizing the publication of this study.

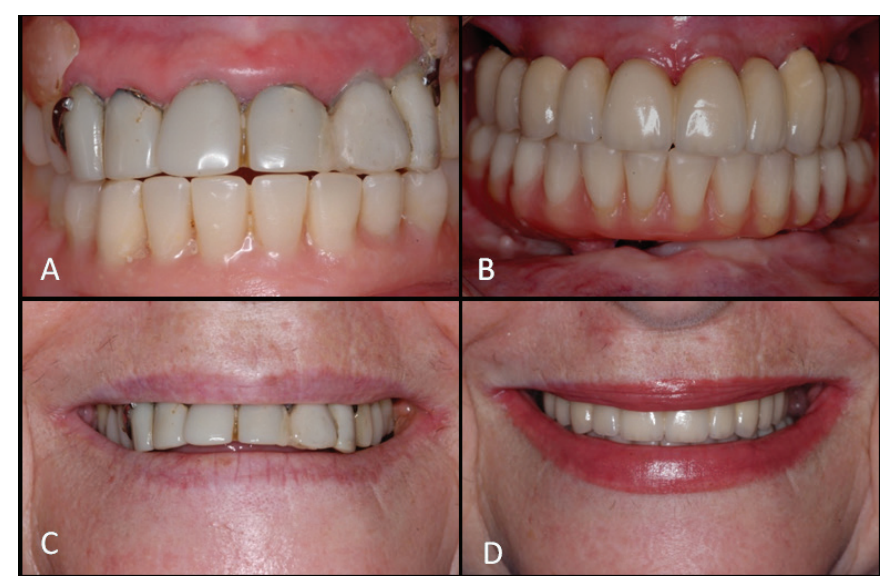

Figure 5. (A) Font view of the initial case; (B) Front view of final case; (C) Patient's smile at the beginning of treatment; (D) Patient's smile at the end of treatment.

\section{DISCUSSION}

Knowledge about Steiner cephalometric tracings were described in 1953, and since them they have been widely used in the orthodontic clinic. Due to the relationship of cranial measurements with the position of maxillary and mandibular central incisors, cephalometry with the Steiner analysis has become a very satisfactory resource for planning in certain cases of oral rehabilitation, however, this type of planning has not been disseminated among dental prosthetists.

In cases of implant placement with immediate load after toothextraction, this previousplanning makesitpossible for the multifunctional guide and temporary dentures to be fabricated in more adequate positions and forms. In the absence of cephalometric analysis, positioning of teeth in the fabrication of immediate dentures and multifunctional guide would occur in an empirical manner, because there would be no possibility of performing try-ins of guidance wax-ups.

To optimize clinical time, in the distal bar technique, the complete removable denture that the patient used before surgery, was transformed into an implant-supported complete fixed denture. For this purpose, conical miniabutments, straight cylinders and those with a distal bar (Neodent, Curitiba, Brazil) with the purpose of reinforcing 
the Cantilever portion of the denture, or GT single bodied implants that dispense with the use of the mini-abutment (Neodent, Curitiba, Brazil) were used. Apart from the clinical time factor and patient satisfaction, this technique allows great passivity of the denture, which is an important factor for the success of osseointegration ${ }^{19}$.

In a literature review, Bilt ${ }^{20}$ pointed out that the maximum masticatory force of subjects who use complete mandibular implant-supported dentures has been shown to be $60-200 \%$ higher than the masticatory force of subjects with conventional complete dentures. As the union between the structures in the distal bar technique is performed with acrylic resin only, this denture is of a temporary nature, and it is necessary for a definitive denture to be fabricated after the period of osseointegration.

Correct control of occlusal forces is determinant for clinical success. For this purpose, some principles of occlusion have been suggested as factors to consider when the occlusion of implant-supported dentures is established, such as the occlusal morphology of the denture orienting the occlusal force in the apical direction, reduced occlusal table, reduced inclination of the cusp, and reduced mesio-distal and vestibularlingual distance of the cantilever ${ }^{21}$. In order to establish

\section{REFERENCES}

1. Pound E. Applying harmony in selecting and arranging teeth. Dent Clin North Am. 1962:241-58.

2. Pound $E$. The vertical dimension of speech: the pilot of occlusion. J Calif Dent Assoc. 1978;6(2):42-7.

3. Pound E. Let ' $S$ ' be your guide. J Prosthet Dent. 1977;38(5):4829. doi: 10.1016/0022-3913(77)90022-1.

4. Bassi F, Rizzatti A, Schierano G, Preti G. Evaluation of the utility of cephalometric parameters in constructing complete denture. Part II: placement of anterior teeth. J Oral Rehabil. 2001;28(4):349-53. doi: 10.1046/j.1365-2842.2001.00668.x.

5. Steiner CC. Cephalometrics for you and me. Am J Orthod. 1953;39(10):729-55. doi: 10.1016/0002-9416(53)90082-7.

6. Steiner CC. The use of cephalometrics as an aid to planning and assessing orthodontics treatment. Am J Orthod. 1960;46(10):721-35. doi: 10.1016/0002-9416(60)90145-7.

7. Tung FF, Coleman AJ, Lu TN, Marotta L. A multifunctional, provisional, implant-retained fixed partial denture. J Prosthet Dent. 2001;85(1):34-9. doi: 10.1067/mpr.2001.112495.

8. Crespi R, Capparè P, Gherlone E, Romanos GE. Immediate occlusal loading of implants placed in fresh sockets after tooth extraction. Int J Oral Maxillofac Implants. 2007;22(6):955-62. an ideal occlusion in implant-supported dentures, prosthetic/surgical planning based on biomechanical principles is necessary ${ }^{21}$.

Therefore treatment with implants greatly improves masticatory function and patient satisfaction for a long period.

\section{CONCLUSION}

It was concluded that the planning and treatment of patients who need tooth extractions and placement of immediate dental prostheses are facilitated with the use of Steiner cephalometric analysis, thus allowing the dentures to be fabricated on a scientific basis, and providing better patient satisfaction.

\section{Collaborators}

AF BORGES, MRM REGO e DM TELLES were responsible for the prosthetic procedures and writing the article. AM CORREAA was responsible for the writing the article. MF TORRES and LC SANTIAGO were responsible for the surgical procedures and writing the article.

9. Barone A, Covani U, Cornelini R, Gherlone E. Radiographic bone density around immediately loaded oral implants. Clin Oral Implant Res. 2003;14(5):610-5. doi: 10.1034/j.16000501.2003.00878.x.

10. De Bruyn $H$, van de Velde t, Collaert B. Immediate functional loading of TiOblast dental implants in full-arch edentulous mandibles: a 3-year prospective study. Clin Oral Implants Res. 2008;19(7):717-23. doi: doi: 10.1111/j.16000501.2008.01533.x.

11. Gallucci GO, Bernard JP, Bertosa M, Belser UC. Immediate loading with fixed screw-retained provisional restorations in edentulous jaws: the pick up technique. Int J Oral Maxillofac Implants. 2004;19(4):524-33.

12. Branemark PI, Engstrand P, Ohrnell LO, Gröndahl K, Nilsson P, Hagberg K, et al. Branemark Novum: a new treatment concept for rehabilitation of the edentulous mandible. Preliminary results from a prospective clinical follow-up study. Clin Implant Dent Relat Res. 1999;1(1):2-16.

13. Maló P, Rangert B, Nobre M. "All-on-four" immediate-function concept with Branemark System implants for completely edentulous mandibles: a retrospective clinical study. Clin Implant Dent Relat Res. 2003;5(Suppl 1):2-9.

14. Maló P, Rangert B, Nobre M. All-on-4 immediate-function concept with Branemark System implants for completely edentulous maxillae: a 1-year retrospective clinical study. Clin Implant Dent Relat Res. 2005;7(Suppl 1):88-94. 
15. Schnitman PA, Wöhrle PS, Rubenstein JE, DaSilva JD, Wang NH. Ten-year results for Brånemark implants immediately loaded with fixed prostheses at implant placement. Int J Oral Maxillofac Implants. 1997;12(4):495-503.

16. Tarnow DP, Emtiaz S, Classi A. Immediate loading of threaded implants at stage 1 surgery in edentulous arches: ten consecutive case reports with 1- to 5-year data. Int J Oral Maxillofac Implants. 1997;12(3):319-24.

17. Tealdo T, Bevilacqua M, Pera F, Menini M, Ravera G, Drago $C$, et al. Immediate function with fixed implant-supported maxillary dentures: a 12-month pilot study. J Prosthet Dent. 2008;99(5):351-60. doi: 10.1016/S0022-3913(08)60082-7.

18. Mish CM. Immediate loading of definitive implants in the edentulous mandible using a fixed provisional prosthesis: the denture conversion technique. J Oral Maxillofac Surg. 2004;62(Suppl 2):106-15. doi: 10.1016/j.joms.2004.06.042.
19. Carlson B, Carlsson GE. Prosthodontic complications in osseointegrated dental implant treatment. Int J Oral Maxillofac Implants. 1994;9(1):90-4

20. Van der Bilt A. Assessment of mastigation with implications for oral rehabilitation: a review. J Oral Rehabil. 2011;38(10):754-80. doi: 10.1111/j.1365-2842.2010.02197.x.

21. Kim Y, Oh TJ, Misch CE, Wang HL. Occlusal considerations in implant therapy: clinical guidelines with biomechanical rationale. Clin Oral Implants Res. 2005;16(1):26-35. 10.1111/j.16000501.2004.01067.x.

Received on: 9/8/2011

Final version resubmitted on: 19/6/2012

Approved on: 30/8/2012 